v. 8, n.2

Vitória-ES, Apr. - Jun. 2011.

p. $92-113 \quad$ ISSN 1808- 2386 DOI: $h$ ttp://dx.doi.org/10.15728/bbr.2011.8.2.5

\title{
Characteristics of companies that influence their voluntary disclosure of performance indicators
}

\author{
Roberto Carlos Klann ${ }^{\dagger}$ \\ Regional University of Blumenau / FURB \\ Ilse Maria Beuren ${ }^{\Omega}$ \\ Regional University of Blumenau / FURB
}

\begin{abstract}
The purpose of the study is to analyze whether characteristics such as size, activity sector and economic-financial performance influence companies to disclose accounting performance indicators in the form of voluntary disclosure in their annual reports. A descriptive research with quantitative approach was conducted through Standardized Financial Statements (DFPs) of 2008 of 90 companies listed in the New Corporate Governance Market of BM\&FBovespa. Having as a reference the research of Watson, Shrives and Marston (2002), based on these statements, performance indicators related to Agency and Signaling Theory and voluntary disclosure were calculated. Considering the dichotomous nature (yes/no) of the dependent variable (disclosure of accounting indicators), and the fact that independent variables (profitability and return on investment, leverage, liquidity, efficiency and activity sector) contain so many categorical data such as value, Watson, Shrives and Marston (2002) used Stepwise Logistic Regression to test research hypotheses, which was also used in this study, to determine which independent variables explain disclosure better. It is concluded that some variables can, in a way, influence voluntary disclosure, even though no sufficiently strong statistical relations have been found. The most significant variables presented by the logistic regression model were the activity sector and operating margin when only some industry groups are analyzed.
\end{abstract}

Keywords: Voluntary disclosure; performance indicators; agency theory; signaling theory.

Authors' correspondence*:

${ }^{\dagger}$ Master by the Post-graduation Program in Accounting Sciences of the Regional University of Blumenau. Link: Regional University of Blumenau

Address: Rua Antônio da Veiga, 140 - Room D 202

Bairro Victor Konder - Post Office Box 1507 CEP 89012-900 -

Blumenau - SC - Brazil

E-mail: rklann@al.furb.br

Telephone: (47)3321-0565

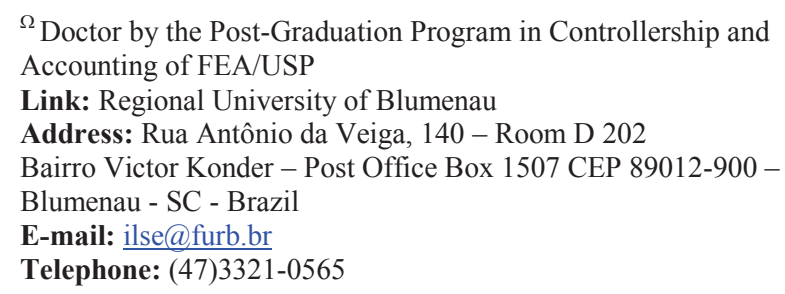

Editor's Note: This paper was accepted by Antonio Lopo Martinez. 


\section{INTRODUCTION}

The presentation of voluntary information on the part of companies has been the subject of studies to explain disclosure growth in the last years. It is speculated that one of the possible justifications may be due to Brazilian stock market growth and the national economy performance, which represents an opportunities to Brazilian companies to raise funds on the stock market. On the other hand, when seeking this source of resources companies are forced to adopt a greater transparence posture in relation to its corporate governance manner.

Another possible explanation may result from the fact of the international financial crisis, which impacted the world stock market, having presented less significant impacts on the Brazilian stock market, when compared to other markets, such as the United States of America, for example. This fact has contributed to an increase of foreign investments in national companies. Therefore, in order to dispute these resources, Brazilian companies were certainly forced to make supplementary disclosures, in addition to those legally required in the country.

Prior studies about voluntary disclosure point out that in Brazil, this kind of information is not yet high, but has quite grown in the last decades (BEUREN, 1991; FALCÃO, 1995). On the other hand, there are also researches that indicate that Brazilian companies little disclose, in addition to strictly required by law (MAFRA; NESS Jr., 2002; PONTE; OLIVEIRA, 2004). In another study, Teixeira, Fortunato and Aquino (2004) related disclosure of additional information to company size, observing that larger companies disclose more. In additional scope, Watson, Shrives and Marston (2002) point out that voluntary disclosure subject has been the target of researchers for several years, such as for instance, Cerf (1961), Firth (1979), Verrecchia (1983 and 1990), Chow and Wong-Boren (1987), Cooke (1989 and 1991), Hossain, Perera and Rahman (1995) and Raffournier (1995).

An interesting remark is that companies keep presenting voluntary disclosure despite the constant increase of mandatory disclosures. The motivation for this behavior has been the focus of attention of several researchers (WATSON; SHRIVES; MARSTON, 2002). The research of Watson, Shrives and Marston (2002) addresses a special kind of voluntary disclosure, of accounting performance indicators in annual corporate reports. According to these authors, this kind of information may be useful to compare the performance of companies. 
Accounting performance indicators must be evidenced by companies in annual reports in order to reduce user's uncertainty, decreasing in this way capital cost to the company. Therefore, this kind of voluntary disclosure may contribute to Brazilian companies, facilitating access to capital and reducing their fundraising costs. In these terms, the research performed herein is justified, which reapplies Watson, Shrives and Marston (2002) study on Brazilian companies.

This study, as well as the research of these authors, uses as a theoretical platform the Agency Theory and the Signaling Theory, in order to consubstantiate the following questionproblem: In which conditions are companies more prone to disclose accounting performance indicators in the form of voluntary disclosure in their annual reports? The study aims to analyze whether characteristics such as size, activity sector and economic-financial performance influence companies to disclose accounting performance indicators in the form of voluntary disclosure in their annual reports.

The study is structured in five sections. In this first section, it presents the theme, the research problem and the purpose of the study. In these sequence, it addresses the theoretical referential that corroborates the study, especially voluntary disclosure, the Agency Theory and Signaling Theory. Afterwards, it presents the research method and procedures, highlighting the variables and hypotheses of the research. Then it describes result analysis, and ends the conclusions of performed research.

\section{THEORETICAL REFERENTIAL}

In this section, a theoretical incursion into voluntary disclosure is made and a brief approach about the Agency Theory and Signaling Theory in order to support the study.

\subsection{Voluntary Disclosure}

Before discussing voluntary disclosure, a few considerations about accounting disclosure are made. Iudícibus (2004, p. 116) comments that "disclosure is not about a convention, but rather as some authors admit, a special chapter of accounting theory. [...] disclosure is connected to accounting objectives, when it ensures differentiated information to several kinds of users".

Iudícibus and Marion (1999, p. 53) comment that the purpose of disclosure, treated as an accounting object, is to "[...] provide structured information of economic, financial and, supplementary physical, productivity and social nature, to internal and external users to the entity object of accounting". 
The kind and amount of disclosure depend on the degree of knowledge of the reader of these reports (IUDÍCIBUS, 2004). First, one must know the profile of the person who will receive this disclosure, in order to understand the amount of information that this individual will be able to "digest". Accounting information may be evidenced in several manners, and it must be tried to convey it in the best possible manner, so that it will be possible to understand and useful to the manager in the decision-making process.

The disclosure of mandatory economic and financial information for open capital companies is regulated by several legal provisions (laws, decrees, regulatory instructions). However, there are disclosures of voluntary character, independent of legal imposition, such as need awareness and respect to the users of this information (MALACRIDA; YAMAMOTO, 2006).

Hendriksen and Van Breda (1999) mention that as companies start to have greater dependence on foreign capital, they tend to provide more appropriate disclosure to the markets where they intend to raise funds. According to Malacrida and Yamamoto (2006), the strongest argument for voluntary disclosure on the part of companies is the strengthening of their image before the Securities Market. This contributes to better financial assessment of the company resulting in lower fund-raising cost, and less price fluctuation of its shares on the market.

Voluntary disclosure comprises any kind of information, contained in annual corporate reports, in addition to legally required ones, in other words, information made available by companies by their own will, in order to inform their stakeholders better, or by convenience, in order to attract investors. Goulart (2003, p. 59) warn that "companies must not restrict themselves, in their disclosure, to information required by law only, also conveying information that, even though they are not compulsory, they collaborate so that the public will establish a correct view about corporate reality".

Companies' decision for greater voluntary disclosure may have different theoretical and practical supports. There are studies that seek to justify companies' decision to disclose or not additional information based on the Agency Theory (CHOW and WONG-BOREN, 1987; COOKE, 1989, 1991, 1992; FIRTH, 1980; WATSON, SHRIVES and MARSTON, 2002) or the Signaling Theory (ECCLES et al., 2001; WATSON, SHRIVES and MARSTON, 2002), both described in the following topics. 


\subsection{Agency Theory}

The Agency Theory has broken the Classical Economic Theory paradigm, where the firm was formed by a single partner, who was also the manager, when considering a model of a firm consisting of a principal (shareholder) as an agent (manager). At the time when the market was basically formed by simple entities, with a single partner, the need for accounting information was limited.

The capital market development throughout the world, with consequent transformation, of several simple entities into complex organizations, with several shareholders and hiring professional to manage the enterprises, caused the need for information about these organizations to grow. Furthermore, the separation between capital and labor, in other words, between shareholders and organization managers created a conflict of interest between them.

Lopes and Martins (2005, p. 28) emphasize that "the emergence of the modern corporation with ownership separated from management has created the possibility that conflicts of interest might emerge between shareholders and managers and even between managers of different levels themselves". The Theory of Agency precisely deals with the problems caused when the interests of managers are not aligned with the organization's interests, which may harm their shareholders.

Among the first studies that approached the Theory of Agency, we can mention the papers of Spence and Zeckhauser (1971) and Ross (1973). These authors analyzed the managers' (agents) compensation structure, in the alignment of their interests with the one of shareholders (principal). A more comprehensive formalization of this theory was made for the first time by Jensen and Meckling (1976), who defined the Agency Theory as a contract where the principal (shareholder) hires the agent (manager) to perform a job in his favor, delegating the decision authority to the agent.

The Agency Theory, according to Siffert Filho (1996), addresses bilateral relations between two individuals (the principal and the agent), in which three necessary conditions must be present:

a) the agent may have various different behaviors, he effectively controls the organization's assets, and may employ them in distinct manner;

b) the agents' action does not only affect their own well-being, but also the principal's (valuation of actions, dividends); 
c) the agent's actions are hardly observable by the principal, there being information asymmetry between them.

The greatest concern in this perspective, according to Kester (1992), is to create efficient mechanisms, such as monitoring systems and incentives, so that the managers' objectives will be convergent with owners' or shareholders' objectives. Conflicts of interests between shareholders and managers may generate costs to the organization. Jensen and Meckling (1976, p. 307) mention as main agency costs:

\footnotetext{
a) contract preparation and structuring costs between the principal and agent;

b) monitoring expenses of agents' activities, such as report preparation, information system and disclosure costs;

c) expenses made by agents themselves, to promote the transparence of information between him and the agent;

d) residual losses, originating from reduction of principal's wealth by misalignment of agent's interests and decisions in relation to principal.
}

The congruence of principal's and agent's objectives is an inherent challenge to corporate management. Since both seek to maximize their usefulness, as a result conflicts come up. Demsetz (1990) observe that agency problems do not only reside in the interaction between the parties, but also within each party, because every individual must deal with himself over the time, in other words, the tastes and capabilities of this individual in the future may not be the same as today.

The Agency Theory has been used as a theoretical platform to try to explain several accounting phenomena. For example, Bitler, Moskowitz and Vissing-Jorgensen (2005) applied the Agency Theory in an enterprising environment, in order to build and test a forecast model by using enterprising effort and wealth data in private companies. Woodward, Edwards and Birkin (2001), when studying evidences about the view of corporate social responsibility executives, used the Agency Theory to establish a connection between the organization and its various interest groups. Verstegen (2001) presented nine manners for the decision maker to use the Agency Theory in the decision process. Dey (2008) investigated whether corporate governance is associated with agency conflict levels in companies.

In this study it is sought to use the Agency Theory to explain in which situations organizations disclose additional voluntary information. According to Watson, Shrives and Marston (2002), managers, knowing that shareholders seek to control their behavior by monitoring activities, may have an encouragement to try to convince shareholders that they are acting in the best manner and disclosure may be a means to achieve it. 
The Agency Theory foresees that agency costs rage according to the size, leverage and listing status. It suggests, for example, that highly leveraged companies would disclose more information in order to meet their stakeholders' needs, seeking to reduce their capital cost by reducing investor's uncertainty (WATSON; SHRIVES; MARSTON, 2002).

Disclosure of performance indicators in reports published by companies can provide accounting statement users with new information, not calculated before, or provide information already available in other reports, but in $\mathrm{u}$ different manner (HOSSAIN, PERERA and RAHMAN, 1995; COOKE, 1989; WATSON, SHRIVES and MARSTON, 2002).

What matters to these authors is that these disclosures facilitated users' understanding of accounting information, improving the quality of annual reports. If these quality improvements enable managers to reduce agency costs, then Agency theory, to these authors, can explain why managers seek to disclose accounting performance indicators in voluntary manner.

\subsection{Signaling Theory}

The Signaling Theory was developed by Spence (1973) to explain the labor market behavior, but according to Watson, Shrives and Marston (2002), it can also explain voluntary disclosures. It consists of a reaction to informational asymmetry in markets. In the specific case of this study, companies have information that investors do not have. This informational asymmetry can be reduced if one party provides the other party with a greater number of information. In this case, high-quality company managers wish to be differentiated from lowquality companies through voluntary disclosures. In order to successfully signal quality, managers understand that this signal has to be reliable (WATSON; SHRIVES; MARSTON, 2002).

Such happens with Agency Theory, at first sight it may seem that Signaling Theory is unable to easily explain disclosures of accounting indexes, because such information is often available in other reports, constituting, therefore, old (known) information. However, if index disclosure is considered the best practice, then this approach can be a sign of quality information (WATSON; SHRIVES; MARSTON, 2002).

If Signaling Theory can explain index disclosure, then, again, attributes of certain companies would be expected to be associated with the disclosure. Particularly, Signaling Theory would support disclosure of certain index types, such as investment, profitability and 
efficiency. These could be disclosed by companies intending to highlight some aspects (presumably favorable) of their performance (WATSON; SHRIVES; MARSTON, 2002).

From the Agency and Signaling Theory discussion it can he noticed that there is a considerable overlapping between both. Morris (1987) investigated whether these two theories are consistent, equivalent or competing, by examining necessary and sufficient conditions for both. The author suggests that sufficient conditions for the Signaling Theory are consistent with those of Agency Theory, then both theories are consistent (WATSON; SHRIVES; MARSTON, 2002).

Morris (1987, p. 52) complements that, "[...] accounting choice forecast, at least, can be improved by additions forecasts of each theory". It seems, therefore, that greater knowledge can be acquired about the reason why managers disclose indexes voluntarily, basing themselves on both theories (WATSON; SHRIVES; MARSTON, 2002). These two theories serve as a basis for this research, which procedures and method adopted to conduct the study are described next.

\section{RESEARCH METHOD AND PROCEDURES}

This section presents the research method and procedures. First the research outline is made, as regards its objectives, approach to the problem and data collection. Next, the research population and sample are described and data collection and analysis procedures.

\subsection{Research outline}

Regarding the research objectives, this study can be characterized as. According to Andrade (2006, p. 124), "in this kind of research, facts are observed, recorded, analyzed, classified and interpreted, without the researcher even interfering in them. This means that the physical and human world phenomena are studied, but are not handled by the researcher".

In relation to the approach to the problem, this research is characterized as quantitative. According to Boudon (1989, p. 24), "quantitative researches can be defined as those that allow collecting, in a set of elements, comparable information between one element and another". This comparability of information allows quantitative data analysis. Therefore, for application of this method, the existence of a set of more or less comparable é elements is indispensable.

When appraising this quantitative research method, Richardson (1999, p. 70) comments that it is characterized by "employing quantification both in information collection and its treatment, through statistical techniques, from the simplest, such as percentage, 
average, standard deviation, to the most complex, such as correlation coefficient, regression analysis, etc".

Data were collected through documental research. According to Silva and Grigolo (2002), this kind of research uses not yet analyzed materials in deepened manner. It aims to select, treat and interpret raw information, in order to contribute with the scientific community. Therefore, regarding data collection this study is based on documental research.

\subsection{Population and sample}

The research population comprises open capital companies listed on BM\&FBovespa (www.bmfbovespa.com.br). The research sample can be classified as intentional. According to Richardson (1999, p. 161), in this kind of sample "the elements that form the sample intentionally relate according to certain characteristics established in the plan and hypotheses formulated by researcher". It was chosen to work with companies listed in the New Corporate Governance Market. The option for this listing segment is justified, because these companies are supposedly committed to high standards of transparence and disclosure.

In this way, 90 companies were selected, from industrial goods (8), civil construction (22), transportation (3), cyclic consumption (10), non-cyclical consumption (20), basic materials (5), oil, gas and biofuels (2), information technology (5), telecommunications (1), public utility (8), highway exploitation (3), real estate brokerage (1) and construction material (2) sectors. Companies classified in the financial sector were not considered, because they present different characteristics from the other companies and that might distort the research results.

\subsection{Data collection and analysis procedures}

Data were collected by means of Standardized Financial Statements (DFPs), relative to 2008. These statements were accessed on BM\&FBovespa website (www.bmfbovespa.com.br). From these statements, performance indicators were calculated that, according to the research performed by Watson, Shrives and Marston (2002), are related to Agency and Signaling Theories and voluntary information disclosure.

The variables used in Watson, Shrives and Marston's research (2002) were as follows: a) profitability and return on investment; b) leverage; c) liquidity; d) efficiency; e) company size; and f) activity sector. These variables were also used in this study, it being that their meaning and derived hypotheses are addressed next. 


\subsubsection{Profitability and return on investment}

With respect to the company's profitability and return on investment, Watson, Shrives and Marston (2002) assert that the Signaling Theory suggests that companies with good performance wish to signal this quality to investors. The Agency Theory also points out to a relationship between disclosure and profitability. Inchausti (1997) argues that many profitable company managers disclose detailed information in order to ensure the continuity of their positions and compensation systems. In this regard, accounting indicators can be one of the forms of these disclosures.

Watson, Shrives and Marston (2002) then present two hypotheses, which are used in this study, to investigate the relationship between profitability and return on investment and disclosure of accounting indicators:

$\mathrm{H}_{1}$ - There is no difference between companies that disclose accounting indicators in financial reports and companies that do not do this kind of disclosure;

$\mathrm{H}_{2}$ - There is no difference between return on investment of companies that disclose accounting indicators in financial reports and companies that do not do this kind of disclosure.

\subsubsection{Leverage}

According to Watson, Shrives and Marston (2002), leverage is related to the company's financial structure and the long-term risk derived from this structure. It reveals the balance between two sources of long-term resources, the amount invested by the partners and the one raised from third parties. A certain degree of leverage is attractive to shareholders, provided that it increases average real return on investment. On the other hand, debts increase financial risk, a high degree of leverage also may indicate an unsustainable level of debts.

Further according to these authors, the Agency Theory may foresee a positive relationship between leverage and disclosure, although it is not necessarily disclosure of leverage indexes. According to Jensen and Meckling (1976), when a company borrows resources, to restrict managers' behavior, the creditors may include certain covenants in loan agreement, starting to monitor these managers. In this way, managers may trip to reduce monitoring costs by voluntarily producing relevant information and publishing this information in financial reports (WATSON; SHRIVES; MARSTON, 2002).

In relation to the Signaling Theory, there also may be a relation between leverage and disclose, although the direction of this relationship is not very clear. Some studies quoted by Watson, Shrives and Marston (2002) point out this relation, such as: Belkaoui and Kahl 
(1978), who show a negative relationship between leverage and disclosure; Gray and Roberts (1989), who point out that the company's capital structure has a positive and significant impact on voluntary disclosure. Watson, Shrives and Marston (2002) then present a third hypothesis, also used in this study:

$\mathrm{H}_{3}$ - There is no difference in leverage of companies that disclose accounting indicators in financial reports and companies that do not do this kind of disclosure.

\subsubsection{Liquidity}

According to Matarazzo (2003, p. 163), liquidity indexes "show the company's financial situation base". However, these indexes do not indicate the company's payment ability, because they are not withdrawn from companies' cash flow. They only indicate "how solid the company's financial base is". These indexes have already been used in insolvency forecast models, such as of Beaver (1966), Altman (1968), among others. To Watson, Shrives and Marston (2002), companies with a secure financial position wish to signal it to investors.

The Agency Theory predicts that agency costs will be greater, the greater the proportion of debits in the company's capital structure is (which may be measured by liquidity indexes). Then, the greater liquidity is, the lower index disclosure on the part of managers will be. Therefore, the Agency Theory foresees an opposite relationship between disclosure and liquidity in relation to the foreseen by the Signaling Theory (WATSON; SHRIVES; MARSTON, 2002).

From these propositions, Watson, Shrives and Marston (2002) have formulated the fourth research hypothesis, also used in this study:

$\mathrm{H}_{4}$ - There is no difference between the liquidity of companies that disclose accounting indicators in financial reports and companies that do not do this kind of disclosure.

\subsubsection{Efficiency}

Watson, Shrives and Marston (2002) assert that efficiency indexes (such as inventory turnover, sales by employees, for example), provide a view on operating efficiency, by indicating how management uses resources at its disposal. The authors ponder that an efficiency increase must lead the company to better performance. On the other hand, companies with unfavorable results may be sensitive to disclosing their efficiency indicators, resulting in a possible relation between the company's efficiency indexes and their disclosure. This means that companies with better performances would be more willing to disclose their efficiency indexes in relation to companies with poor performance. 
From this reasoning, Watson, Shrives and Marston (2002) following research hypothesis, also used in this study::

$\mathrm{H}_{5}$ - There is no difference in the efficiency companies that disclose accounting indicators in financial reports and companies that do not do this kind of disclosure.

\subsubsection{Size}

There are countless reasons to assume that the company size is related to its level of voluntary disclosure. In small companies, the cost of producing additional voluntary information may be much greater, proportionately, if compared to large companies. Additionally, large companies usually obtain greater benefits with voluntary disclosure, such as capital cost reduction, for example, in relation to small companies (WATSON; SHRIVES; MARSTON, 2002).

The authors quote as an example the studies of Singhvi and Desai (1971), Buzby (1975), Belkaoui and Kahl (1978), Chow and Wong-Boren (1987), Cooke (1989), Gray and Roberts (1989), who found a relation between company size and the level of disclosure.

In this way, Watson, Shrives and Marston (2002) formulated a hypothesis to test this relation, which was also used in this study:

$\mathrm{H}_{6}-$ There is no difference between the size of companies that disclose accounting indicators in financial reports and companies that do not do this kind of disclosure.

\subsubsection{Industry (activity sector)}

The relation between the kind of industry and the degree of disclosure does not seem to be very clear. Watts and Zimmerman (1986) assert that industry works as a confusion factor, becoming a proxy for size. However, according to Watson, Shrives and Marston (2002), there are recent evidences that suggest that size and kind of industry are closely connected by all activity sectors.

To these authors, the Agency Theory might explain disclosure differences between industries that are highly regulated, motivated to disclose information in order to reduce agency costs (for compliance with legislation). While the Signaling Theory provides a more advantageous justification to these disclosure differences, according to these authors, because certain companies may want to demonstrate that they are complying with the best disclosure practices of certain indexes. 
According to Watson, Shrives and Marston (2002), although there are no clear evidences about this relation (industry $\mathrm{x}$ disclosure), it is interesting to test whether disclosure varies among several industries (activity sectors). To this end, they have formulated the following hypothesis, also used in this study:

$\mathrm{H}_{7}$ - There is no difference in the disclosure of accounting indicators between companies of different activity sectors.

\subsubsection{Hypothesis test}

The Agency Theory and Signaling Theory suggest a number of variables that may be associated with disclosure. In order to test raised hypotheses, Watson, Shrives and Marston (2002) used the multivariate analysis, as well as other studies about voluntary disclosure, such as Cooke (1989, 1992), Hassain et al. (1994) and Raffournier (1995).

Given the dichotomous nature (yes/no) of the dependent variable (disclosure of accounting indicators), and independent variables contain so many categorical data such as value, Watson, Shrives and Marston (2002) decided to use Logistical Regression as a tool to test the research hypotheses, which was also used in this research. Among the several logistical regression models, Stepwise Model was used, to determine which independent variables explain disclosure better. The independent variables used from data collected from researched companies' accounting statements were:

a) profitability - measured by operating margin and return on employed capital;

b) return on investment - measured by the dividend per share;

c) leverage - measured by the relation between debts and shareholders' equity;

d) liquidity - measured by current liquidity rate;

e) efficiency - Watson, Shrives and Marston (2002) used sales per employee as efficiency measure. It did not occur in this research, because it was not possible the access the number of employees of several companies. In this case, it was chosen to use asset turnover as efficiency measure;

f) size - measured by total asset amount;

g) industry (activity sector) - ranked according to BM\&FBovespa segments: industrial goods; civil construction; highway exploitation; real estate brokering; construction material; transportation; cyclical consumption; non-cyclical consumption; basic materials; oil, gas and biofuels; information technology; telecommunications; and public utility. 
In this way, the study limitation result from strategies chosen to outline this research. The main limitations concern chosen indexes and selected company samples, it being that research findings only apply to investigated situations. Another aspect of possible interference in the comparative with the study used as a reference consists of the differences in considered environments, especially capital market competitiveness, which may strongly influence companies' voluntary disclosure.

\section{DATA DESCRIPTION AND ANALYSIS}

Analyzed companies are listed on BM\&FBovespa, in new corporate governance market segment. Ninety companies were identified, divided into 13 operation sectors, as described in Table 1.

TABLE 1 - ACTIVITY SECTORS OF ANALYZED COMPANIES

\begin{tabular}{lccc}
\hline \multicolumn{1}{c}{ Industry } & N & $\begin{array}{c}\text { Companies that disclose } \\
\text { indicators }\end{array}$ & $\%$ \\
\hline Industrial goods & 8 & 6 & $75 \%$ \\
Civil construction & 22 & 8 & $37 \%$ \\
Cyclical consumption & 10 & 9 & $90 \%$ \\
Non-cyclical consumption & 20 & 13 & $65 \%$ \\
Basic materials & 5 & 3 & $60 \%$ \\
Oil, gas and biofuels & 2 & - & - \\
Information technology & 5 & 2 & $40 \%$ \\
Telecommunications & 1 & 1 & $100 \%$ \\
Public utility & 8 & 4 & $50 \%$ \\
Transportation & 3 & - & - \\
Highway exploitation & 3 & 3 & $100 \%$ \\
Real estate brokering & 1 & - & - \\
Construction material & 2 & 1 & $50 \%$ \\
\hline Total & 90 & 50 & $56 \%$ \\
\hline Source: research data & & &
\end{tabular}

Source: research data.

Table 1 shows that the most significant groups in terms of number of companies are civil construction (22 companies), non-cyclical consumption (20) and cyclical consumption (10) groups. The highest disclosure percentages are in telecommunications and highway exploitation groups. However, this fact is due to the small number of analyzed companies in these sectors, which renders this kind of analysis unfeasible in this case. In larger groups, the one that presents the highest disclosure percentage is cyclical consumption (90\%). Civil construction group presents low disclosure percentage, with only $37 \%$.

However, in order meet the research hypotheses, it is necessary to analyze the companies jointly, with previously selected variables. Using the logistical regression model, first all the companies and all variables were analyzed, in order to determine which independent variable better explains the dependent variable behavior (disclosure). After this analysis, each hypothesis was tested individually, with its respective variable, in order to determine its acceptance or not. 
After these calculations, some dummy variables were also created, in order to try to increase the predictive value of the model. Results are presented in Table 2.

TABLE 2 - LOGISTICAL REGRESSION MODEL RESULT

\begin{tabular}{|c|c|c|c|c|c|c|c|c|}
\hline \multirow[t]{2}{*}{ evar } & \multirow[t]{2}{*}{ Considered variables } & \multirow[t]{2}{*}{$\beta$} & \multirow[t]{2}{*}{$\begin{array}{l}\text { Signifi } \\
\text { cance }\end{array}$} & \multirow[t]{2}{*}{$\begin{array}{l}\% \text { Correctly } \\
\text { classified }\end{array}$} & \multicolumn{2}{|c|}{$\begin{array}{l}\text { Hosmer and } \\
\text { Lemeshow Test } \\
\text { Model) }\end{array}$} & \multicolumn{2}{|c|}{$\begin{array}{l}\text { Omnibus Test of } \\
\text { Model Coefficients } \\
\text { (Step*, Block and }\end{array}$} \\
\hline & & & & & $\begin{array}{l}\text { Chi- } \\
\text { Square }\end{array}$ & $\begin{array}{l}\text { Signific } \\
\text { ance }\end{array}$ & $\begin{array}{l}\text { Chi- } \\
\text { Square }\end{array}$ & $\begin{array}{l}\text { Signific } \\
\text { ance }\end{array}$ \\
\hline \multirow{3}{*}{ n } & Constant & $-0,293$ & 0,065 & & & & & \\
\hline & Liquidity & 0,885 & 0,030 & $60,0 \%$ & 5,085 & 0,748 & 4,738 & 0,30 \\
\hline & Operating margin & 0,003 & 0,946 & & & & & \\
\hline \multirow[t]{2}{*}{1} & $\begin{array}{l}\text { Return on employed } \\
\text { capital }\end{array}$ & 0,322 & 0,458 & & & & & \\
\hline & Constant & 0,224 & 0,293 & $56,7 \%$ & 9,268 & 0,320 & 0,662 & 0,718 \\
\hline \multirow{2}{*}{ ○ } & Dividend per share & 0,244 & 0,489 & & & & & \\
\hline & Constant & 0,135 & 0,583 & $55,6 \%$ & 7,735 & 0,171 & 0,498 & 0,480 \\
\hline \multirow{2}{*}{ 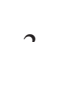 } & Debts on PL & $-0,007$ & 0,494 & & & & & \\
\hline & Constant & 0,253 & 0,242 & $55,6 \%$ & 12,470 & 0,131 & 0,547 & 0,459 \\
\hline \multirow{2}{*}{1} & Liquidity & $-0,293$ & 0,065 & & & & & \\
\hline & Constant & 0,885 & 0,030 & $60,0 \%$ & 5,085 & 0,748 & 4,738 & 0,030 \\
\hline \multirow{2}{*}{$\tau$} & Asset turnover & 0,212 & 0,577 & & & & & \\
\hline & Constant & 0,067 & 0,850 & $55,6 \%$ & 6,044 & 0,418 & 0,314 & 0,575 \\
\hline \multirow{8}{*}{ r } & Total assets & 0,000 & 0,657 & & & & & \\
\hline & Constant & 0,151 & 0,571 & $55,6 \%$ & 11,835 & 0,159 & 0,200 & 0,654 \\
\hline & Civil construction & 0,000 & 0,692 & & & & & \\
\hline & Non-cyclical consumption & 20,643 & 1,000 & & & & & \\
\hline & Industrial goods & 21,822 & 1,000 & & & & & \\
\hline & Cyclical consumption & 22,302 & 1,000 & & & & & \\
\hline & Information technology & 23,400 & 1,000 & & & & & \\
\hline & Oil & 20,797 & 1,000 & & & & & \\
\hline \multirow{10}{*}{7} & Highway exploitation & 0,000 & 1,000 & & & & & \\
\hline & Basic materials & 42,406 & 0,999 & & & & & \\
\hline & Public utility & 21,608 & 1,000 & & & & & \\
\hline & Construction material & 21,203 & 1,000 & & & & & \\
\hline & Telecommunications & 21,203 & 1,000 & & & & & \\
\hline & Transportation & 42,406 & 0,999 & & & & & \\
\hline & Real estate exploitation & 0,000 & 1,000 & & & & & \\
\hline & Constant & $-21,203$ & 1,000 & $70,0 \%$ & 0,000 & 1,000 & 26,092 & 0,010 \\
\hline & Civil construction & 0,000 & 0,223 & & & & & \\
\hline & Non-cyclical consumption & $-19,324$ & 0,994 & & & & & \\
\hline \multirow[t]{5}{*}{8} & Cyclical consumption & $-17,966$ & 0,995 & & & & & \\
\hline & Operating margin & 1,044 & 0,677 & & & & $* 6,677$ & 0,10 \\
\hline & Constant & 18,608 & 0,994 & $71,2 \%$ & 10,668 & 0,221 & 16,287 & 0,001 \\
\hline & Civil construction & 0,000 & 0,216 & & & & & \\
\hline & Non-cyclical consumption & $-15,252$ & 0,966 & & & & & \\
\hline \multirow{4}{*}{ n } & Industrial goods & $-13,936$ & 0,969 & & & & & \\
\hline & Cyclical consumption & $-13,517$ & 0,970 & & & & & \\
\hline & Operating margin & 0,804 & 0,732 & & & & $* 6,618$ & 0,10 \\
\hline & Constant & 14,573 & 0,967 & $71,7 \%$ & 6,605 & 0,580 & 17,141 & 0,002 \\
\hline
\end{tabular}

Source: research data.

Table 2 presents the variables included in each test, along with their coefficient $\beta$ and the degree of significance of each variable in the model. It also presents the predictive power of each model. Furthermore, in order to reinforce found results, Table 2 also presents Hosmer and Lemeshow test and Omnibus Test results for Model Coefficients. 
Hosmer and Lemeshow Test (HLT) deals with a Chi-Square test, which purpose is to test the hypothesis that there are no differences between results predicted by the model and those observed. The greater the level of significance in this test, the better it is (CORRAR; PAULO; DIAS FILHO, 2009).

The Omnibus Test Model Coefficients (OTMC) tests the hypothesis that all logistical equation coefficients are null. If test results are significant, the hypothesis that estimated parameters are null can be rejected, in other words, they contribute to improve the quality of predictions (CORRAR; PAULO; DIAS FILHO, 2009). It is important in logistical regression to perform several tests in order to test the validity of each model, because each test has its limitations.

The zero test presented in Table 2 included all studied variables, by using a stepwise type logistical regression, which selects the variables that better explain the behavior of predicted variable (disclosure). In this case, the only selected variable was liquidity, all other being discarded. However, the model's hit percentage was low, with only $60 \%$ hit in classification. HLT result presents a satisfactory level of significance, however, this result is not confirmed by the OTMC, which does not present a satisfactory result. Therefore, it cannot be stated that this model is valid to explain voluntary disclosure of indicators.

From tests 1 to 7 , all research hypotheses were tested, relating the variable of each hypothesis to the dependent variable. The test that presented the highest model hit percentage was number 7 , which related industry type to disclosure. The model presented a $70 \%$ hit percentage. HLT and OTMC results also point out to the model's predictive validity.

Next tests 8 and 9 were performed. In test 8 , only civil construction, non-cyclical consumption and cyclical consumption activity sectors were used, in addition to all other variables, by applying stepwise type logistical model. The choice for these specific sectors occurred because they represent the most numerous company groups. The model then discarded all other variables, only keeping profitability, measured by the operating margin, as the variable that better explains variation in the disclosure in these specific activity sectors. The model's hit percentage presented a slight increase, to $71.2 \%$. However, Hosmer and Lemeshow Test presented a low model significance index, not being possible to accept the hypothesis that there are no significant differences between expected and observed values. Omnibus Test results for Model Coefficients demonstrate significance, mainly in Block and Model tests. Due to non-consistence between test results, it cannot be statistically stated that model 8 has a valid predictive value. 
In test 9 , in turn, industrial goods sector was added to the three activity sectors of test 8 , the fourth with the largest number of companies, in order to improve the model's predictive value. Again, operating margin (profitability) was the only selected variable. The model's hit percentage increased a little more, to $71.7 \%$. Again HLT and OTMC results found in the previous test were repeated, which shows that the model cannot be considered statistically relevant.

When comparing the results of these tests with Watson, Shrives and Marston research (2002), it is verified that hit percentages of the models of these authors (from $74 \%$ to 86 $\%)$ were higher than those presented in Table 2. However, in some aspects, they are similar.

Watson, Shrives and Marston results (2002) show greater explanation power in "industry type" variable. It also occurred in this research, when comparing results of tests 7 to 9 to those of tests 0 to 6 . By it, it can be inferred that industry type ends up, in a way, influencing the disclosure of accounting indicators, although this relation was stronger in Watson, Shrives and Marston's paper (2002), and less intense in this research.

Another similarity between the two studies is that when using some specific activity sectors, logistical regression only selected one variable for each activity sector composition, which was observed in both studies. What changed, in this case, is that in this research the only selected variable was operating margin (profitability), while in Watson, Shrives and Marston's research (2002) other variables were selected in each activity sector composition.

An important difference in both studies is that Watson, Shrives and Marston's research (2002) points out as prevalent variables for performance indicator disclosure the activity sector and company size. The latter did not appear in any of the tests presented in Table 2 of this study. Therefore, while for English companies, the size influences voluntary accounting indicator disclosure, in Brazil, this variable does not seem to be important.

Another important difference in these two studies is that, on average, from $78 \%$ to $86 \%$ of English companies researched by Watson, Shrives and Marston (2002) voluntarily disclosed accounting indicators, versus only $56 \%$ of Brazilian companies. This demonstrates that in terms of quality of disclosed accounting information, Brazilian companies, generally speaking, need to evolve, making more information available to their stakeholders.

\section{CONCLUSIONS}

The study aimed at analyzing whether characteristics such as size, activity sector and economic and financial performance influence companies to disclose accounting performance 
indicators in the form of voluntary disclosure in their annual reports. Descriptive research with quantitative approach was performed by means of Standardized Financial Statements (DFPs) of 2008 of 90 companies listed on BM\&FBovespa New Corporate Governance Market segment. Based on these financial statements, performance indicators were calculated and hypotheses tested by using Stepwise Logistical Regression, as well as occurred in Watson, Shrives and Marston's research (2002), in order to determine which independent variables explain disclosure better.

From the research result analysis, it is concluded that some variables can, in a way, influence this kind of disclosure, although no sufficiently strong statistical relations have been found. The most significant variables presented by the logistical regression model were industry type and operating margin, when only some industry groups are analyzed.

About industry type, the Agency Theory, as already explained before, can explain disclosure differences between highly regulated industries, which disclose information in order to reduce agency costs. As the analysis occurred with BM\&FBovespa Corporate Governance New Market segment, it can be inferred that the Securities and Exchange Commission (CVM) requirements and o other regulatory agencies contribute to greater disclosure of these indicators.

However, even though in Brazil the disclosure percentage is relatively low (56\%), it is observed that industry type may be relevant both in the case of disclosure, and in the case of non-disclosure. This problem also was found by Watson, Shrives and Marston (2002) in their research. They verified that some sectors, even being regulated presented low disclosure indexes. In this case, which is contrary to the Agency Theory, they justified by quoting Wallace, Naser and Mora (1994), who argued that large companies exposed to political attacks may be motivated to disclose less information to the market, protecting themselves from harmful political actions.

In relation to profitability (operating margin), the Signaling Theory, as already explained before, suggests that companies that have good performance wish to signal this quality to investors. Whereas the Agency Theory points out that managers of profitable companies may disclose detailed information in order to ensure continuity of their positions and compensation systems. Therefore, in a way, results of tests 8 and 9 are consistent with these two theories, indicating that profitability may influence de disclosure of performance indicators in voluntary manner in annual results, at least in those four analyzed activity sectors (civil construction, non-cyclical consumption, cyclical consumption and industrial goods). 
Regarding the research hypotheses, the results found in the research allow partially rejecting hypotheses $\mathrm{H}_{1}$ (profitability) and $\mathrm{H}_{7}$ (industry). Partial rejection is justified because logistical model hit percentage remained around $71 \%$ and $72 \%$. Whereas for the other hypotheses, the results do not support their rejection, no significant influence being observed in any of the other variables in the explanation of disclosure or not of accounting indicators in annual reports.

The differences observed in the results of the preceding research, of Watson, Shrives and Marston (2002), with this research, may be justified by several factors. One of them may result from the volume and maturity of the United Kingdom stock market, if compared to Brazilian stock market. Because they are more accustomed to trade in this kind of market, English companies may be more acquainted with investors' needs, market analysts, among other users of information contained in annual reports. Furthermore, it also must be considered that the sample used by Watson, Shrives and Marston (2002) was larger (approximately 250 companies), with a longer analysis period (reports from 1989 to 1993), comparatively to this research, which may cause differences in results.

Although some relations have been verified between performance indicator disclosure and the research variables, generally speaking, based on the foregoing, as well as in Watson, Shrives and Marston study (2002), it is concluded that there are limited indications that support the recommendation in the Signaling Theory and Agency Theory, specifically concerning voluntary disclosure of accounting performance indicators.

The research results cause some uneasiness, which is presented as suggestions for future studies. Expansion of the analysis period, insertion other activity sectors and other BM\&FBovespa listing segments are recommended. Brazilian companies that have ADRs overseas also may be the subject of analysis, checking whether for the foreign market there are differences of information voluntary disclosure.

\section{REFERENCES}

ANDRADE, M. M. Introdução à metodologia do trabalho científico. 7. ed. São Paulo: Atlas, 2006.

BEUREN, I. M. Divulgação de informações voluntárias em relatórios financeiros e seu relacionamento com a estrutura das empresas e características dos contabilistas. 1991. 101 f. Dissertação (Mestrado em Ciências Contábeis) - Curso de Pós-Graduação em Ciências Contábeis, Fundação Getúlio Vargas, Rio de Janeiro, 1991.

BITLER, M. P.; MOSKOWITZ, T. J.; VISSING-JORGENSEN, A. Testing Agency Theory with entrepreneur effort and wealth. The Journal of Finance. v. 60, n. 2, Apr. 2005. 
BOUDON, R. Os métodos em sociologia. São Paulo: Ática, 1989.

CERF, R.A. Corporate reporting and investment decisions. Berkeley: University of California Press. 1961.

CHOW, C. W.; WONG-BOREN, A. Voluntary financial disclosure by Mexican corporations. The Accounting Review, v. LXII, n. 3, p. 533-541, July, 1987.

COOKE, T. E. Voluntary corporate disclosure by Swedish companies. Journal of International Financial Management and Accounting, v. 1, n. 2, p. 171-195, 1989.

COOKE, T. E. An assessment of voluntary disclosure in the annual reports of Japanese corporations. International Journal of Accounting, v. 26, n. 3, p. 174-189, 1991.

CORRAR, Luiz J.; PAULO, Edilson, DIAS FILHO, José Maria. Análise Multivariada: para os cursos de administração, ciências contábeis e economia. 1. ed. 2. reimpr. São Paulo: Atlas, 2009.

DEMSETZ, H. Ownership control and the firm: the organization of the economic activity. Massachusetts: Basil Blackwell, 1990. v. 1.

DEY, A. Corporate governance and agency conflicts. Journal of Accounting Research. v. 46, n. 5, 2008.

ECCLES, R. G. et al. The value reporting revolution: moving beyond the earnings game. PricewaterhouseCoopers. New York: John Wiley \& Sons, Inc., 2001.

FALCÃO, E. Divulgação em demonstrações financeiras de companhias abertas. Caderno de Estudos, FIPECAFI - FEA/USP, n. 12, set. 1995.

FIRTH, M. The impact of size, stock market listing, and auditors on voluntary disclosure in corporate annual reports. Accounting and Business Research, n. 9, p. 273-280, Autumn, 1979.

GOULART, A. M. C. Evidenciação contábil do risco de mercado por instituições financeiras no Brasil. 2003. 201 f. Dissertação (Mestrado em Controladoria e Contabilidade) - Programa de Pós-Graduação em Controladoria e Contabilidade, Faculdade de Economia, Administração e Contabilidade da Universidade de São Paulo, São Paulo, 2003.

HENDRIKSEN E. S.; VAN BREDA, M. F. Teoria da contabilidade. 5 ed. São Paulo: Atlas, 1999.

HOSSAIN, M.; PERERA, M. H. B.; RAHMAN, A. R. Voluntary disclosure in the annual reports of New Zealand companies. Journal of International Financial Management and Accounting. v. 6, n. 1, p. 69-85, 1995.

IUDÍCIBUS, S. Teoria da contabilidade. 7. ed. São Paulo: Atlas, 2004.

IUDÍCIBUS, S.; MARION, J. C. Introdução à teoria da contabilidade para o nível de graduação. São Paulo: Atlas, 1999.

JENSEN, M. C.; MECKLING, W. H. Theory of the firm: managerial behavior, agency costs and ownership structure. Journal of Financial Economics, n. 3, p. 305-360, 1976. 
KESTER, W. C. Industrial groups as systems of contractual governance. Oxford Review of Economic Policy, v. 8, n. 3, p. 24-44, Autumn, 1992.

LOPES, A. B.; MARTINS, E. Teoria da contabilidade: uma nova abordagem. São Paulo: Atlas, 2005.

MAFRA, M. A. F; NESS JR, W. L. O relatório da administração no Brasil: peça de informação ou de ficção. In: ENANPAD, 26., 2002, Curitiba. Anais... Rio de Janeiro: ANPAD, 2002. CD-ROM.

MALACRIDA, M. J. C.; YAMAMOTO, M. M. Governança corporativa: nível de evidenciação das informações e sua relação com a volatilidade das ações do iBOVESPA.

Caderno de Estudos, FIPECAFI - FEA/USP, Edição Comemorativa, set. 2006.

MORRIS, R.D. Signalling, agency theory \& accounting policy choice. Accounting \& Business Research. v. 18, n. 69, p. 47-56, 1987.

PONTE, V. M. R.; OLIVEIRA, M. C. A prática da evidenciação de informações avançadas e não obrigatórias nas demonstrações contábeis das empresas brasileiras. Revista

Contabilidade \& Finanças, FEA/USP, n. 36, p. 07-20. set./dez. 2004.

RAFFOURNIER, B. The determinants of voluntary financial disclosure by Swiss listed companies. The European Accounting Review, v. 4, n. 2, p. 261-280, 1995.

RICHARDSON, R. J. Pesquisa social: métodos e técnicas. 3. ed. São Paulo: Atlas, 1999.

ROSS, S. A. The economic theory of agency: the principal's problem. American Economic Review, v. 63, issue 2, papers and proceedings of the $85^{-}$Annual Meeting of the American Economic Association, p. 134-139, 1973.

SIFFERT FILHO, N. A teoria dos contratos econômicos e a firma. 1996. $201 \mathrm{f}$. Tese (Doutorado em Ciências Econômicas) - Departamento de Economia da Universidade de São Paulo, São Paulo, 1996.

SILVA, M. B.; GRIGOLO, T. M. Metodologia para iniciação científica à prática da pesquisa e da extensão II. Caderno Pedagógico. Florianópolis: UDESC, 2002.

SPENCE, M.; ZECKHAUSER, R. Insurance, information and individual action. American Economic Review, v. 61, n. 2, papers and proceedings of the $83^{\text {rd }}$ Annual Meeting of the American Economic Association, p. 380-387, May, 1971.

SPENCE, M. Job market signaling. Quarterly Journal of Economics. p. 355-374, 1973.

TEIXEIRA, A. C. C.; FORTUNATO, G.; AQUINO, A. C. B. Relação entre transparência e o valor de mercado das empresas brasileiras de capital aberto. In: CONGRESSO USP DE CONTROLADORIA E CONTABILIDADE, 4., 2004, São Paulo. Anais ... São Paulo: FEA/USP, 2004. CD-ROM.

VERRECCHIA, R. E. Discretionary disclosure. Journal of Accounting and Economics, n. 5, p. 179-194, 1983.

VERRECCHIA, R. E. Information quality and discretionary disclosure. Journal of Accounting and Economics, v. 12, n. 4, p. 365-380, 1990. 
VERSTEGEN, B. H. J. Nine ways for a decision maker to use theoretical notions, with special reference to teaching agency theory for management accounting. Journal of Accounting Education. n. 19, p. 119-127, 2001.

WALLACE, R. S. O.; NASER, K.; MORA, A. The relationship between the comprehensiveness of corporate annual reports and firm characteristics in Spain. Accounting and Business Research, v. 25, n. 97, p. 41-53, 1994.

WATSON, A.; SHRIVES, P.; MARSTON, C. Voluntary disclosure of accounting ratios in the UK. British Accounting Review. n. 34, p. 289-313, 2002.

WATTS, R. L.; ZIMMERMAN, J. L. Positive accounting theory. Englewood Cliffs: Prentice Hall, 1986.

WOODWARD, D.; EDWARDS, P.; BIRKIN, F. Some evidence on executive's views of corporate social responsibility. British Accounting Review. n. 33, p. 357-397, 2001. 